Portland State University

PDXScholar

4-1983

\title{
Clutch Size in the Eastern Kingbird: Factors Affecting Nestling Survival
}

Michael T. Murphy

Portland State University, murphym@pdx.edu

Follow this and additional works at: https://pdxscholar.library.pdx.edu/bio_fac

Part of the Biology Commons, and the Ornithology Commons

Let us know how access to this document benefits you.

\section{Citation Details}

Murphy, M. T. (1983). Clutch size in the Eastern Kingbird: factors affecting nestling survival. The Auk, 326-334.

This Article is brought to you for free and open access. It has been accepted for inclusion in Biology Faculty Publications and Presentations by an authorized administrator of PDXScholar. Please contact us if we can make this document more accessible: pdxscholar@pdx.edu. 


\title{
CLUTCH SIZE IN THE EASTERN KINGBIRD: FACTORS AFFECTING NESTLING SURVIVAL
}

\author{
Michael T. MuRPhY \\ The Museum of Natural History, Department of Systematics and Ecology, \\ The University of Kansas, Lawrence, Kansas 66045 USA
}

\begin{abstract}
Observational and experimental procedures were used to evaluate the potential importance of brood size and weather on the evolution of clutch size in the Eastern Kingbird. Modal clutch size was three eggs, yet broods of four were most productive. Nestling size varied inversely with brood size, so that "nestling quality" was lower in broods of four than in broods of three. Asymptotic weight of nestlings in broods of three was directly and significantly correlated with ambient air temperature, followed by hatch order. Because larger broods were being fed during a period of relatively cool and wet weather, the effects of brood size were probably confounded by weather-induced changes in food availability, suggesting that the ability to produce surviving young successfully from large broods is dependent upon weather conditions during the nestling period. These observations match patterns seen in other aerial foragers and indicate that unpredictable changes in temperature and precipitation dramatically affect the ability of the adults to feed young. A high variance in fledging success from the largest broods is indicated and probably selects for a reduced number of offspring in the Eastern Kingbird. Trade-offs in reproductive effort and parental survival do not appear to be required to explain patterns of clutch size in the Eastern Kingbird or, probably, other aerial foragers. Received 13 November 1981, accepted 11 November 1982.
\end{abstract}

INTEREST in the evolution of clutch size in birds stems from the work of David Lack (1947). He proposed that clutch size was an evolved trait, the number of eggs laid by nidicolous birds being determined by the ability of the adults to feed the young. Their heritability and, therefore, evolutionary potential of clutch size has been established (Perrins and Jones 1974; Noordwijk et al. 1981), yet a critical prediction of Lack's "food limitation" hypothesis, that the most common clutch size would also be the most productive brood size, has often not been supported (Haartman 1971, Crossner 1977, Murphy 1978, Cronmiller and Thompson 1980, De Steven 1980).

The causes for this apparent contradiction no doubt vary, for many factors could determine optimal clutch size (i.e. that number of eggs that maximizes expected fitness per offspring and not just the number of young fledged; Brockelman 1975). In some studies (e.g. Cronmiller and Thompson 1980) young in larger broods have fledged at lower weights and sometimes apparently have not survived as well as heavier young from smaller broods (Perrins 1965). Such results support Lack's hypothesis. At the same time, however, it has been predicted that the size of a clutch will be less than the maximum number of young that can be fed when (a) intense competition favors the production of larger, competitively superior offspring (Brockelman 1975), (b) the variance in fledging success from the largest brood sizes is high (Gillespie 1977), or (c) the total lifetime production of young is lessened due to an increased mortality among birds raising larger broods (Williams 1966, Charnov and Krebs 1974, Snell and King 1977, Askenmo 1979). Still others have suggested that clutch size is proximately limited by the amount of energy and/ or protein that is available for egg production at the time of ovulation (Jones and Ward 1976, Murphy 1978), or that clutch size is individually optimized (Schifferli 1978).

Relatively few passerines breeding in north temperate regions have modal clutch sizes of three eggs (O'Connor 1981), and those that do generally breed in forest habitats (Brewer and Swander 1977). The Eastern Kingbird (Tyrannus tyrannus) breeds in grassland to forest-edge habitats, has a model clutch size of only three eggs (Davis 1941, Bent 1942, Murphy in press), is single-brooded, and is also exceptional in having a period of post-fledging parental care that extends for 5 or more weeks (Morehouse and Brewer 1968). Kingbirds thus invest heavi- 
ly in a relatively small number of young each year. In order to understand the ultimate factors resposible for the evolution of a given reproductive effort (i.e. number and size of offspring), it is first necessary to document the proximate factors affecting nestling survival. Weather conditions, because of their affects on insect flight activity (Bryant 1975), are important determinants of nestling growth and survival in aerial insectivores. The majority of Eastern Kingbird prey captures are of flying insects (Leck 1971, Murphy pers. obs.), suggesting that weather may also be important to nestling growth in kingbirds. Using observational and experimental (brood-size enlargement) procedures, I attempted to document the impact of weather and brood size on the growth of Eastern Kingbird nestlings in order to determine their relative importance in the evolution of the clutch size of kingbirds.

\section{Methods}

Data were gathered on Eastern Kingbrids breeding in Erie County, western New York from May to August 1979. The center of my research site was located $16 \mathrm{~km}$ from Lake Erie, about midway between the towns of Eden and Angola $\left(42^{\circ} 40^{\prime} \mathrm{N}, 78^{\circ} 57^{\prime} \mathrm{W}\right)$. Descriptions of the study site, general field procedures, and climatic data for 1979 are given in Murphy (in press). Weather was essentially normal during the period of study.

Nests usually were visited every second or third day. At each visit I measured the weight and the lengths of the tarsus and ninth primary of each nestling. Most nestlings were of known age. Ages of nestlings found after hatching were estimated using weight and length measurements in a technique previously described (Murphy 1981). Most nestlings hatched asynchronously in clutches of three and four, i.e. over 2 or 3 days. Eggs hatching on the same day hatch at least several hours apart. I was therefore able to identify nestlings' hatch order by visiting a nest two or three times on the day of hatching. When two hatchlings appeared between successive visits, I estimated hatch order using a combination of the dryness of natal down (the drier the down, the earlier the hatching) and skin color (skin progressively darkens as birds age).

I subsequently attempted to obtain measurements of nestlings on day 14 (hatching = day 1) for estimating "nestling quality." I assumed the quality of a nestling (its future probability of survival) to be directly correlated with its size. Hence, I gathered data that would enable me to detect [using a single classification analysis of variance (ANOVA)], differ- ences in weight and tarsus and ninth-primary length at 7 days of age for weight and at 14 days for weight and tarsus and ninth-primary length. With the exception of weight on day 14, all comparisons were made of actual measurement data. In place of day 14 weight I used asymptotic weight $\left(X_{0}\right)$, calculated from a least-squares regression procedure outlined by Crossner (1977). I chose to use $X_{0}$ because the determination of weight can be affected by several uncontrolled variables (time of day, length of time since last feeding, or weather conditions). Crossner's $X_{0}$ should more accurately reflect the nestling's entire growth history. Data used in the regression were corrected for unequal measurement intervals.

Brood size ranged from 1 to 5 . Clutches of 1 and 5 did not occur naturally, so that broods of 1 and 5 were the result of egg or nestling attrition or of experimental modification of brood size. Two broods of five young were created by adding a freshly hatched fifth nestling to two broods of four young on the day of hatching of the last nestling. More extensive modification of brood size was not possible because of the limited number of simultaneously occurring, accessible nests. Brood size was considered to have changed from the initial size only if a nestling disappeared before 7 days of age and then only when nestling size was being considered. Productivity and length of the nestling period (hatching of first nestling to fledging of the brood) were compared using initial brood size in all cases. Sample sizes for productivity are generally larger than for comparisons of nestling size, because not all nests where productivity could be measured were accessible to measurement of nestlings.

Environmental influences on final nestling size were investigated using a step-down multiple regression. The dependent variable was asymptotic weight $\left(X_{0}\right)$. Environmental variables acting within the nest that may affect size are brood size, hatching order, and initial size (Bryant 1978). These and seven external environmental variables were included in the analysis as predictor variables. The external environmental variables were date (calculated using 1 May as day 0) and six climatic variables, which were number of days with rain greater than $0.1 \mathrm{~mm}$, mean maximum daily temperature, and overall mean daily temperature, all three calculated over the entire nestling period and for only the latter half of the same period. Weather data were obtained from a weather station located $32 \mathrm{~km}$ away in Fredonia, New York. Fredonia is also close to Lake Erie. Mean daily temperature was the average of the daily minimum and maximum temperatures. This analysis was limited to nests found no later than the first day after hatching, because the hatch order of most nestlings could be estimated accurately up to this point. I subtracted the average growth increment between days 1 and 2 from the day 2 weight of nestlings first weighed on 
TABLE 1. Nestling size in relation to brood size for (a) weight at 7 and 14 days of age, (b) tarsus length, and (c) ninth primary length at 14 days of age for nestling Eastern Kingbirds.

\begin{tabular}{|c|c|c|c|c|c|}
\hline & \multicolumn{5}{|c|}{ Brood size } \\
\hline & 1 & 2 & 3 & 4 & 5 \\
\hline \multicolumn{6}{|c|}{ (a) Weight (g) } \\
\hline \multicolumn{6}{|c|}{7 days $^{a}$} \\
\hline$n$ & 5 & 5 & 26 & 13 & 8 \\
\hline $\bar{x}$ & 22.9 & 20.0 & 21.6 & 21.0 & 20.1 \\
\hline $\mathrm{SD}$ & $(1.88)$ & $(4.91)$ & $(2.01)$ & $(1.84)$ & $(1.08)$ \\
\hline \multicolumn{6}{|c|}{14 days $^{b}$} \\
\hline$n$ & 7 & 6 & $29^{c}$ & $15^{\mathrm{c}}$ & 10 \\
\hline $\bar{x}$ & 37.2 & 36.5 & 34.2 & 31.5 & 24.7 \\
\hline SD & $(2.17)$ & $(1.95)$ & $(3.07)$ & $(3.44)$ & $(2.96)$ \\
\hline \multicolumn{6}{|c|}{ (b) Tarsus $(\mathrm{mm})^{\mathrm{d}}$} \\
\hline $\bar{x}$ & 19.4 & 19.3 & 18.8 & 18.8 & 18.2 \\
\hline SD & $(0.64)$ & $(0.28)$ & $(0.65)$ & $(0.72)$ & $(0.73)$ \\
\hline \multicolumn{6}{|c|}{ (c) Primary $(\mathrm{mm})^{\mathrm{d}}$} \\
\hline $\bar{x}$ & 35.2 & 33.8 & 34.1 & 32.4 & 27.6 \\
\hline $\mathrm{SD}$ & $(3.32)$ & $(2.85)$ & $(2.33)$ & $(3.48)$ & $(4.50)$ \\
\hline
\end{tabular}

actual weight at 7 days of age.

${ }^{b}$ Asymptotic weight predicted from the least squares regression procedure.

c Two nestlings that starved at 10 days of age were excluded.

d Sample sizes the same as for weight at 14 days of age.

that day in order to estimate initial size. A strong correlation between weights on days 1 and $2(r=$ $0.90, n=40$; Murphy unpubl. data) justified this.

\section{RESUlts}

Brood size effects. - The weight of nestlings at 7 days of age was independent of brood size (Table 1. ANOVA $F_{4,52}=1.80, \mathrm{~ns}$ ), but by day 14 significant differences in weight (Table 1. ANOVA $\left.F_{4,60}=26.8, P<0.001\right)$ and tarsus and ninth primary length were evident (Table 1. ANOVAs $F_{4,60}=4.16, P<0.005$ and $F_{4,60}=$ $8.65, P<0.001$, respectively). Nestling weights progressively decreased with increasing brood size; the asymptotic weight of nestlings in broods of 1 was $51 \%$ greater than the asymptotic weight of nestlings in broods of 5 . Corresponding figures for tarsus and ninth primary length were $6.6 \%$ and $27.5 \%$, respectively. Not surprisingly, weight and ninth primary length exhibited a strong positive correlation on day $14(r=0.665, \mathrm{df}=52, P<0.001)$, evident even within broods of three $(r=0.571$, $\mathrm{df}=25, P<0.001$ ). Thus, "nestling quality" was significantly affected by brood size at 14 days of age but not before 7 days of age. A restriction of the analysis of weight variation to broods of natural size (2-4 young) also resulted in a significant effect of brood size on weight (ANOVA) $F_{2,47}=6.63, P<0.001$ ) at 14 days of age.

The coefficient of variation of nestling weights at day 14 for each brood size also exhibited a significant increase with brood size $(r=0.952, \mathrm{df}=3, P<0.05)$, indicating a greater range of weights within the larger brood sizes. This suggests that low nestling weights in the larger broods may have been the result of a "runt" phenomenon and not a whole-brood effect. To test for this, weights of nestlings in broods of 3,4 , and 5 were analyzed with respect to hatch order. Only in broods of four was the effect of hatch order significant, with last-hatched nestlings having the lowest weights (Table 2). Although nestling weights also tended to vary inversely with hatch order in broods of five, the effect was not significant. It is obvious, however, that nestling weights were uniformly low in the two broods of five (Table 2. range $=19.0-27.7 \mathrm{~g}$ ). Low nestling weights in broods of five were therefore a whole-brood phenomenon but were also due, at least partly, to small last-hatched nestlings in broods of four.

Excluding losses to predators, productivity 
TABLE 2. Nestling weight ( $g$ ) in relation to hatch order for broods of 3,4 , and 5 young. Values are means, with standard deviation in parentheses.

\begin{tabular}{|c|c|c|c|}
\hline \multirow{2}{*}{$\begin{array}{l}\text { Hatch } \\
\text { order }\end{array}$} & \multicolumn{3}{|c|}{ Brood size ${ }^{a}$} \\
\hline & 3 & 4 & 5 \\
\hline 1 & $\begin{array}{l}32.9 \\
(3.82)\end{array}$ & $\begin{array}{l}31.6 \\
(1.91)\end{array}$ & $\begin{array}{l}26.2 \\
(2.05)\end{array}$ \\
\hline 2 & $\begin{array}{l}34.3 \\
(2.19)\end{array}$ & $\begin{array}{l}33.3 \\
(3.53)\end{array}$ & $\begin{array}{l}26.3 \\
(1.56)\end{array}$ \\
\hline 3 & $\begin{array}{l}33.8 \\
(2.92)\end{array}$ & $\begin{array}{l}32.7 \\
(2.64)\end{array}$ & $\begin{array}{l}25.9 \\
(0.99)\end{array}$ \\
\hline 4 & - & $\begin{array}{l}26.9 \\
(3.40)\end{array}$ & $\begin{array}{l}22.8 \\
(4.38)\end{array}$ \\
\hline 5 & - & - & $\begin{array}{l}22.2 \\
(4.50)\end{array}$ \\
\hline$F^{b}$ & 0.49 & $3.88^{*}$ & 0.86 \\
\hline
\end{tabular}

a Sample size for broods of 3,4 , and 5 are 9, 4, and 2 nests, respectively.

b Value of the $F$-statistic for a single classification ANOVA of weight variation with respect to hatch order. ${ }^{*}=P<0.05$.

was greatest for broods of 4 , followed by broods of 3 (Table 3). The relationship between the percentage of broods losing at least one nestling to starvation and brood size, however, is significant $(r=0.955, \mathrm{df}=3, P=0.01)$, indicating that the frequency of nestling starvation increased with brood size. In both broods of 5,3 nestlings starved. In no other nest did more than one nestling die of starvation. The average age of starvation was heavily skewed toward the end of the nestling period; only one nestling starved at an age of less than 10 days. The average age of starvation was 12.5 days
$(\mathrm{SD}=3.57, n=13)$. In 6 of 8 nests where the identity of the starved nestling was known, it was the nestling last to hatch. Predation was more frequent on broods of four (2/7 nests $=$ $28.6 \%)$ than on broods of three $(1 / 20$ nests $=$ $5.0 \%)$, although the difference is not significant $(t=1.54, \mathrm{df}=25, \mathrm{~ns})$.

Nestling period ranged from 15 to 19 days, with 17 days being most common. The length of the nestling period was significantly affected by brood size (Table 3. ANOVA $F_{4,24}=13.4$, $P<0.001$ ), with the average length of the nestling period increasing with brood size. The 2 broods of 5 each required a minimum of 19 days to fledge, the third 19-day nestling period occurring in a brood of 4 .

Environmental influences on final size.-The multiple regression relating final nestling size to various environmental factors again indicated that brood size was the major source of variation in final nestling size. The correlation between brood size and asymptotic weight $(r=$ $-0.771, \mathrm{df}=50, P<0.001$ ) was the strongest of three significant correlations, the other two being between asymptotic weight and mean temperature over the entire nestling period $(r=0.527$, $P<0.001)$ and between asymptotic weight and number of rainy days over the second half of the nestling period $(r=-0.313, P<0.05)$. Partial correlations between the latter two variables and final nestling size after entry of brood size into the regression were near zero $(r=$ 0.065 and $r=0.060$, respectively), due to the strong correlations between brood size and

TABLE 3. The influence of initial brood size on (a) productivity (number of young to fledge) and (b) length of the nestling period in Eastern Kingbirds.

\begin{tabular}{|c|c|c|c|c|c|}
\hline & \multicolumn{5}{|c|}{ Brood size } \\
\hline & 1 & 2 & 3 & 4 & 5 \\
\hline \multicolumn{6}{|l|}{ (a) Productivity } \\
\hline$n$ & 7 & 16 & 60 & 28 & 10 \\
\hline Number to fledge & 7 & 13 & 53 & 17 & 4 \\
\hline Number starving & 0 & 1 & 4 & 3 & 6 \\
\hline Number depredated & 0 & 2 & 3 & 8 & 0 \\
\hline $\bar{x}$ Productivity $^{\mathrm{a}}$ & 1.0 & 1.9 & 2.8 & 3.4 & 2.0 \\
\hline $\mathrm{SD}^{\mathrm{b}}$ & $(0.00)$ & $(0.38)$ & $(0.42)$ & $(0.55)$ & $(0.00)$ \\
\hline \multicolumn{6}{|l|}{ (b) Nestling period length } \\
\hline$n$ & 5 & 3 & 14 & 5 & 2 \\
\hline $\bar{Y}$ (days) & 15.0 & 16.7 & 16.8 & 17.8 & 19.0 \\
\hline $\mathrm{SD}$ & $(0.71)$ & $(0.58)$ & $(0.80)$ & $(0.84)$ & $(0.00)$ \\
\hline
\end{tabular}

a Productivity excludes losses to predators

b Standard deviation of productivity per nest excluding depredated nests. 
mean temperature over the nestling period $(r=$ $-0.642, \mathrm{df}=50, P<0.001$ ) and between brood size and number of rainy days over the latter half of the nestling period $(r=0.450, P<0.001)$. Unfortunately, nestlings in the largest brood sizes were being fed during a period of cold and wet weather, so that brood size and climatic influences on final nestling size could not be separated. The fact that 10 of the 14 nestlings to starve did so during several days of below-average temperatures immediately following five consecutive days of rain (Fig. 1) indicates that external environmental variables, in addition to brood size, probably had significant effects on nestling growth and survival. Figure 1 indicates that during the inclement weather brood-size effects became operational at progressively earlier ages as brood size increased.

To investigate further the potential influence of environmental factors on final nestling size, a second multiple regression was computed for broods of three alone. I chose to use only broods of three because (1) their occurrence spanned the entire breeding season and (2) they provided the largest sample size. The strongest correlations with asymptotic weight were of mean temperature over the entire nestling pe$\operatorname{riod}(r=0.516, \mathrm{df}=22, P<0.01)$, mean temperature over the latter half $(r=0.414, \mathrm{df}=$ $22, P<0.05)$, and hatch order $(r=0.389, \mathrm{df}=$ 22, $0.05<P<0.10)$. The correlation between date and asymptotic weight was not significant $(r=0.305, \mathrm{df}=22, \mathrm{~ns})$. Results of the first three steps in the multiple regression are presented in Table 4. Mean temperature over the entire nestling period entered the regression first, followed by hatch order (partial correlation $=$ $0.454 ; \mathrm{df}=2,21 ; 0.05<P<0.10$ ). With the inclusion of hatch order the multiple coefficient of determination $\left(R^{2}\right)$ increased from $26.7 \%$ to $41.8 \%$ of the variance in final nestling size. Thus, second- and third-hatched nestlings in broods of three, being fed when ambient temperatures were high, had the greatest asymptotic weights.

\section{Discussion}

Brood size, climatic variation and nestling weights.-From observations of the growth of nestling Eastern Kingbirds in different-sized broods being fed under varying conditions of air temperature and precipitation, I reach three conclusions:
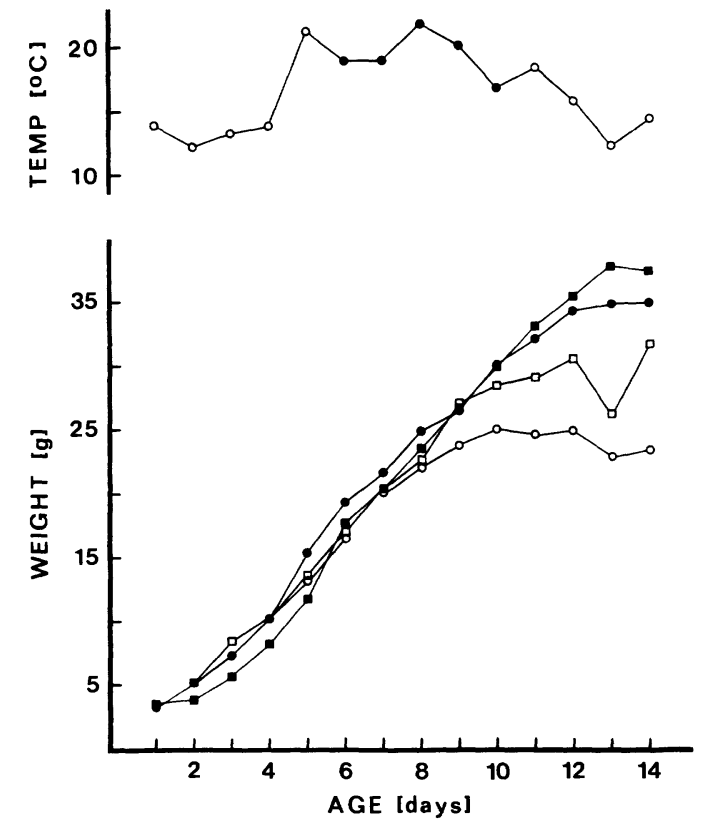

Fig. 1. Average growth curves (weight gain) for young in broods of 2 (solid squares; $n=1$ nest), 3 (solid circles; $n=3$ nests), 4 (open squares; $n=2$ nests), and 5 (open circles; $n=2$ nests) hatching about 23 June ( \pm 1 day). Mean ambient air temperature for each day of the nestling period on which these young were being fed in the nest is plotted in the upper curve. Precipitation exceeded $0.1 \mathrm{~mm}$ for 5 consecutive days beginning on day 6 (solid circles). Note the lack of differences in weight gain before day 8 . Brood-size effects became apparent by day 9 and were amplified up to the end of the measurement period. Ten nestlings starved between days 10 and 15 .

(1) Final nestling size decreased, but frequency of nestling starvation and length of nestling period increased, with an increase in brood size. That individual optimization of clutch size (e.g. Schifferli 1978) was not a major factor in these results is suggested by the fact that for broods that corresponded to the original number of eggs laid, significant negative effects of brood size were also detected. Hence, individual optimization of clutch size to differences in "parental quality" (e.g. foraging abilities; Bryant 1979, Bryant and Westerterp 1982) was not a main cause for the significant brood-size effects.

(2) Within broods of three young, final nestling size was directly and significantly correlated with air temperature. Weather conditions apparently also had a major impact on nestling 
TABLE 4. Regression equations relating final nestling size in broods of three to initial size, hatch order, date, and six climatic variables in a stepwise multiple regression.

\begin{tabular}{llc}
\hline & \multicolumn{1}{c}{ Regression equation $^{\mathrm{a}}$} & $R^{\mathrm{b}}$ \\
\hline Step 1 & $Y=-48.9+1.26$ (AIRTEMP) & 0.516 \\
Step 2 & $Y=-51.8+1.26$ (AIRTEMP) +1.42 (HATORD) & 0.646 \\
Step 3 & $Y=-73.7+1.58$ (AIRTEMP + 1.42(HATORD) +0.35 (RAIN) & 0.669 \\
\hline
\end{tabular}

${ }^{\text {a }}$ AIRTEMP = mean air temperature over entire nestling period; HATORD = hatching order of the nestlings; RAIN = number of rainy days over entire nestling period.

${ }^{\mathrm{b}}$ Multiple correlation coefficient for each regression equation.

starvation in all brood sizes, as most nestlings that starved did so during a period of low temperatures and high precipitation.

(3) Broods of five exhibited disproportionately low weights and unusually heavy starvation. Both broods experienced the worst weather of the season; 5 days of light-to-medium rain were followed by several days of below average temperatures. Hence, effects attributed to brood size were probably amplified by the impact of cool, wet weather on the abilities of the adults to feed the young.

The frequency of nestling starvation among "aerial filtering" birds (swallows and swifts) is also greatest during inclement weather (Apus apus, Lack and Lack 1951; Progne subis, Allen and Nice 1952; Tachycineta bicolor, Chapman 1955, Stewart 1972; Hirundo pyrrhonota, Stewart 1972). Davies (1977) observed considerable nestling starvation in Spotted Flycatchers (Muscicapa striata) during periods of rain, when the availability of flying insects was observed to decrease. My observations of the negative impact of inclement weather on the growth and survival of nestling Eastern Kingbirds, which has also been documented in another kingbird population (P. J. Blancher pers. comm.), is probably also related to decreased food availability. Although flycatchers use entirely different foraging methods from those of swallows or swifts, they too are generally dependent upon flying insects for food.

Alternative sources of food.-Although Eastern Kingbirds regularly eat fruit (Leck 1971, Stapanian 1982) and are able to use alternative methods of foraging, they are predominantly aerial foragers. The availability of flying insects to aerially foraging birds is decreased during periods of cool and/or wet weather (Taylor 1963; Bryant 1975, 1978; Davies 1977), and, because of the nestlings' high protein requirements, fruit is probably not a suitable food substitute for most nestling birds (Ricklefs 1976). There- fore, because nestlings must be fed insects, their food supply probably fluctuates with weather. This suggests that the relatively lightweight individuals in broods of three and the extremely small nestlings in broods of five resulted from short-term reductions in the availability of flying insects. An alternative explanation, that broods of five could not be fed because of behavioral limits of adult feeding rates (Hussel 1972), is not supported by field observations. Fruit (mulberries, Morus sp.) became a common food item of nestlings in broods of five, and to a lesser extent in broods of four, during the cool and wet period. The protein and lipid content of mulberries is low (King and McClure 1944). Nestlings were therefore receiving an inferior food source, suggesting an inability of the adults to locate sufficient insect food during poor weather.

Brood-size manipulation.-The findings reported here are contrary to the results of broodsize manipulation experiments of Eastern Kingbirds in Kansas (Murphy unpubl. data). Broods of five in Kansas have not experienced weather as severe as that which occurred in 1979 in New York, and differences in nestling size and in the frequency of nestling starvation in different-sized broods has not been observed. In neither population were broods of three the most productive brood size. Broods of four are consistently the most productive. The asymptotic weight and overall size of nestlings in New York fledging from broods of four, however, were less than those of nestling fledging from broods of three. If the potential for future survival of a nestling is directly related to its size at fledging (Perrins 1965, Howe 1976, Garnett 1981; but see De Steven 1980, Ross and McClaren 1981), then it is possible that relatively more of the nestlings fledging from broods of three would survive to the next breeding season. This seems almost certain when one considers the very small nestlings 
fledging from broods of five, but differences in size between nestlings fledging from broods of three and four may be eliminated during the the period of prolonged post fledging parental care. Because feeding rate does not peak until 10-14 days after fledging (Morehouse and Brewer 1968), however, maximum energy demands by the young occur after they have left the nest. The co-occurrence of large brood size and poor weather at this time would probably result in even greater fledgling starvation. It therefore seems probable that the productivity of broods of four is more variable than that of broods of three, despite the prolonged care that fledgling kingbirds receive.

Gillespie (1977) has theoretically demonstrated that a high variance in fledging success from the largest brood sizes selects for reduced offspring number. The inability of kingbirds to predict the onset and duration of cool and wet weather exposes individuals attempting to raise broods of five to a high risk of reproductive failure. Therefore, it may be best to attempt to raise fewer young than can normally be raised to independence under good conditions if the likelihood of complete reproductive failure increases dramatically with the unpredictable but potential onset of stressful conditions. The weather encountered in 1979 was not unusual, because the average length of the greatest number of consecutive days of rain in June in New York is about 4 days $(\bar{x}=4.2$, $\mathrm{SD}=1.86$ days, range $=2-8$ days, $n=15 \mathrm{yr}$; NOAA 1952-1955, 1971-1981). Patterns observed in 1979 were therefore not anomalous and occur regularly but at unpredictable intervals. Hence, it is probable that both small clutch size and prolonged parental care have evolved in the Eastern Kingbird to avoid complete reproductive failure during periodically stressful conditions.

Further observations of the breeding biology of the Eastern Kingbird support this conclusion. Rapid starvation of nestlings is a wasteful strategy for aerial insectivores because of the variable nature of their food supplies. Slow nestling development minimizes the chance of prematurely starving nestlings (Lack and Lack 1951, O'Connor 1978). Eastern Kingbirds develop relatively slowly for open-nesting passerines in north temperate regions (Murphy in press). I also found egg size to increase with laying order in New York (Murphy in press). This would tend to equalize nestling size and therefore competitive abilities arising from hatching asynchrony, which would also tend to minimize the probability of young starving unnecessarily during a temporary loss of food (Howe 1976). Increasing egg size probably also explains why, in broods of three, later-hatched nestlings tended to be heavier than first-hatched young. These traits, and the association of most nestling starvation with cold, wet weather, are typical of other aerial insectivores (Lack and Lack 1951; Chapman 1955; Bryant 1975, 1978; Davies 1977) and suggest the operation of common selective pressures in the evolution of their life histories (O'Connor 1978).

Trade-offs in reproductive effort and parental survival therefore do not appear to be required to explain patterns of clutch size either in the Eastern Kingbird or in other birds that use aerial foraging methods and that are able to raise larger than average broods (e.g. Tachycineta bicolor, De Steven 1980). The success of Tree Swallows in raising larger than average broods is probably attributable to the absence of particularly stressful feeding conditions during the period of study, especially because, in this species, nestling starvation during periods of cool, wet weather has been documented to be high (Chapman 1955, Stewart 1972). The arguments thus presented are similar to those offered by Lack and Lack (1951) to explain the evolution of clutch size in the European Swift (Apus apus) and may therefore be a general phenomenon among birds that capture insects in flight.

\section{ACKNOWLEDGMENTS}

I am indebted to the many landowners who allowed me accesss to their property. I also thank R. F. Johnston, K. A. Crossner, and D. M. Bryant for providing critical readings of this and earlier manuscripts. My writing and interpretation of data were much improved by their comments. The Northeastern BirdBanding Association provided funds that made this study possible. My wife, Karmel Licata, also helped with expenses and helped in a variety of other ways.

\section{Literature Cited}

Allen, R. W., \& M. M. Nice. 1952. A study of the breeding biology of the Purple Martin (Progne subis). Amer. Midl. Natur. 47: 606-665.

Asкenmo, C. 1979. Reproductive effort and the survival rate of male Pied Flycatchers Ficedula hypolecua. Amer. Natur. 113: 748-753. 
Bent, A. C. 1942. Life histories of North American flycatchers, larks, swallows and their allies. U.S. Natl. Mus. Bull. 179.

Brewer, R., \& L. Swander. 1977. Life history factors affecting the intrinsic rate of natural increase of birds of the deciduous forest biome. Wilson Bull. 89: 211-232.

Brockelman, W. Y. 1975. Competition, the fitness of offspring, and optimal clutch size. Amer. Natur. 109: 677-699.

$\rightarrow$ BRYANT, D. M. 1975. Breeding biology of houst martins Delichon urbica in relation to aerial insect abundance. Ibis 117: 180-216.

$\rightarrow$ 1978. Environmental influences on growtl $\rightarrow$ and survival of nestling house martins Delichon urbica. Ibis 120: 271-283.

-. 1979. Reproductive costs in the house martin Delichon urbica. J. Anim. Ecol. 48: 655-675.

$\longrightarrow \rightarrow-$, \& K. R. Westerterp. 1982. Evidence for individual differences in foraging efficiency amongst breeding birds: a study of house martins Delichon urbica using the doubly labelled water technique. Ibis 124: 187-192.

$\rightarrow$ Chapman, L. B. 1955. Studies of a Tree Swallow colony. Bird-Banding 26: 45-70.

$\rightarrow$ Charnov, E. L., \& J. R. Krebs. 1974. On clutchsize and fitness. Ibis 116: 217-219.

Cronmiller, J. R., \& C. F. Thompson. 1980. Experimental manipulation of brood-size in Redwinged Blackbirds. Auk 97: 559-565.

Crossner, K. A. 1977. Natural selection and clutch size in the European Starling. Ecology 58: 885892.

$\rightarrow$ Davies, N. B. 1977. Prey selection and the search strategy of the Spotted Flycatcher (Muscicapa striata): a field study on optimal foraging. Anim. Behav. 25: 1016-1033.

$\rightarrow$ Davis, D. E. 1941. The belligerency of the kingbird. Wilson Bull. 53: 157-168.

De Steven, D. 1980. Clutch size, breeding success and parental survival in the Tree Swallow (Iridoprocne bicolor). Evolution 34: 278-291.

$\rightarrow$ Garnett, M. C. 1981. Body size, its heritability and influence on juvenile survival among great tits, Parus major. Ibis 123: 31-41.

Gillespie, J. H. 1977. Natural selection for variance in offspring number: a new evolutionar $\rightarrow$ principle. Amer. Natur. 111: 1010-1014.

HaArtman, L. von. 1971. Population dynamics $\rightarrow$ Pp. 391-459 in Avian biology, Vol. 1 (D. S. Farner, J. R. King, and K. C. Parkes, Eds.). New York, Academic Press.

Howe, H. F. 1976. Egg size, hatching asynchrony, sex and brood reduction in the Common Grackle. Ecology 57: 1195-1207.

$\rightarrow$ Hussel, D. J. T. 1972. Factors affecting clutch size in arctic passerines. Ecol. Monogr. 42: 317-364.

Jones, P. J., \& P. WARD. 1976. The level of protein as the proximate factor controlling the timing of breeding and clutch size in the red-billed quelea (Quelea quelea). Ibis 118: 547-574.

King, T. R., \& H. E. McClure. 1944. Chemical composition of some American wild feedstuffs. J. Agricul. Research 69: 33-46.

$\rightarrow$ LACK, D. 1947. The significance of clutch size. Ibis 89: 302-352.

- \& E. LAcK. 1951. The breeding biology of the swift, Apus apus. Ibis 93: 501-548.

LECK, C. F. 1971. Some spatial and temporal dimensions of kingbird foraging-flights. Wilson Bull. 83: 310-311.

Morehouse, E. L., \& R. Brewer. 1968. Feeding of nestling and fledgling Eastern Kingbirds. Auk 85: 44-54.

Murphy, E. C. 1978. Seasonal variation in reproductive output of House Sparrows: the determination of clutch size. Ecology 59: 1189-1199.

Murphy, M. T. 1981. Growth and aging of nestling Eastern Kingbirds and Eastern Phoebes. J. Field Ornithol. 52: 309-316.

- In press. The breeding biology of Eastern Kingbirds: geographic comparisons. Ecology.

National Oceanic and Atmospheric AdminisTRATION. 1952-1955, 1971-1980. Climatological Data, numbers 5-8. Asheville, North Carolina, Environmental Data and Information Service, National Climatic Center.

Noordwijk, A. J. van, J. H. van Balen, \& W. SCHARLOO. 1981. Genetic and environmental variation in clutch size of the Great Tit (Parus major). Netherlands J. Zool. 31: 342-372.

O'ConNor, R. J. 1978. Growth strategies of nestling passerines. Living Bird 16: 209-238.

_. 1981. Comparisons between migrant and non-migrant birds in Britain. Pp. 167-196 in Animal migration (O. J. Aidley, Ed.). Society for Experimental Biology Symposium Series. Cambridge, England, Cambridge Univ. Press.

Perrins, C. M. 1965. Population fluctuations and clutch-size in the Great Tit, Parus major L. J. Anim. Ecol. 34: 601-647.

- \& P. J. Jones. 1974. The inheritance of clutch size in the Great Tit (Parus major L.). Condor 76: 225-229.

RICKLEFS, R. E. 1976. Growth rates of birds in the humid New World Tropics. Ibis 118: 179-207.

Ross, H. A., \& I. A. McLaren. 1981. Lack of differential survival among young Ipswich Sparrows. Auk 98: 495-502.

SCHIFFERLI, L. 1978. Experimental modification of brood size among house sparrows Passer domesticus. Ibis 120: 365-369.

SNell, T. W., \& C. E. King. 1977. Lifespan and fecundity patterns in rotifers: the cost of reproduction. Evolution 31: 882-890.

StAPANIAN, M. A. 1982. Evolution of fruiting strat- 
egies among fleshy-fruited plant species of eastern Kansas. Ecology 63: 1422-1431.

Stewart, R. M. 1972. Nestling mortality in swallows due to inclement weather. California Birds 3: 69-70.

TAYLOR, J. R. 1963. An analysis of the effects of temperature on insects in flight. J. Anim. Ecol. 32: 99-117.

Williams, G. C. 1966. Natural selection, the costs of reproduction and a refinement of Lack's principle. Amer. Natur. 106: 687-690.

Hoffman*, Göran Högstedt*, John Holmes, Richard T. Holmes*, John L. Hoogland, Henry F. Howe, Marshall A. Howe*, Donald F. Hoyt, John P. Hubbard, Raymond B. Huey, Maryanne R. Hughes, Philip S. Humphrey, George L. Hunt, Jr.*, R. Hutto, George Innis, Jerome A. Jackson, Frances C. James*, Olli Järvinen*, Joseph R. Jehl, Jr.*, Donald A. Jenni*, Paul A. Johnsgard, Douglas H. Johnson, Ned K. Johnson*, P. J. Jones, John A. Kadlec, Herbert W. Kale, II, H. Källander, Alan C. Kamil ${ }^{*}$, Janet Kear, J. P. Kelsall, S. Charles Kendeigh, Brina Kessel, Lloyd F. Kiff*, Ben King, James R. King*, Richard W. Knapton, Mike Kochert*, Amélie Koehler, Walter D. Koenig*, Gary Krapu*, John R. Krebs, Donald E. Kroodsma*, James A. Kushlan, Wesley E. Lanyon*, Mary K. Le Croy*, Ross Lein*, Robert E. Lemon*, Sara Lenington, Michael R. Lennartz, J. David Ligon*, Alan Lill*, Clare S. Lloyd, Robert K. Loflin, Peter Lowther, James F. Lynch, Richard E. MacMillen, Michael H. MacRoberts, William J. Maher, Henry Marks, Peter R. Marler*, Chris Marsh, William W. Marshall*, Carl D. Marti*, L. D. Martin, Thomas E. Martin*, Steven Martindale*, Barbara W. Massey, Paul F. Matray, Harold F. Mayfield, Donald A. McCrimmon, Jr., Roy W. McDiarmid, Sam McDowell, Frank McKinney, M. Robert McLandress*, Joseph A. L. Mertens, L. Richard Mewaldt, David Miller*, E. H. Miller*, Richard S. Miller, Douglas W. Mock*, Burt L. Monroe, Jr.*, William A. Montevecchi*, Gerard Morel, Michael L. Morrison*, Douglass H. Morse, Eugene S. Morton*, Martin L. Morton, W. F. Morzer Bruyns, James A. Mosher*, Helmut C. Mueller*, John N. Mugaas, Ronald Mumme, Edward C. Murphy, Mary Murphy, Bertram G. Murray, Jr., Peter Myers*, Bryan Nelson*, David N. Nettleship, Ian Newton*, David M. Niles, Ian Nisbet, Val Nolan, Jr.*, Barry R. Noon, A. J. van Noordwijk, R. A Norberg, Stephen Nowicki, Thomas D. Nudds*, Raymond J. O'Connor*, M. A. Ogilvie, Harry M. Ohlendorf*, Richard R. Olendorff, Storrs L. Olson, John P. O’Neill*, P. Opdam, Lewis W. Oring*, Myrfyn Owen, Ray B. Owen, Jr., C. V. Paganelli, Geoff Parker, P. Parker-Rabenold, Kenneth C. Parkes*, John Paton, Samuel M. Patten, Jr., John Patton, Robert B. Payne*, David L. Pearson*, R. E. Phillips, Raymond Pierotti, Benedict C. Pinkowski, Frank A. Pitelka, George V. N. Powell, Harry W. Power, III*, Peter Prince, Kerry N. Rabenold*, Robert

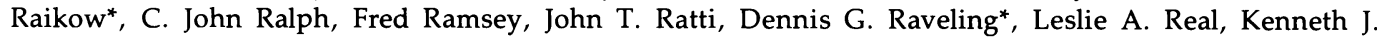
Reinecke, James V. Remsen, Jr. *, Heinz-Ulrich Reyer, Richard Reynolds*, Jake Rice, Terrell D. Rich, W. John Richardson*, Robert E. Ricklefs*, Robert W. Risebrough, James D. Rising*, Mark Robbins, Raleigh Robertson, William B. Robertson, Jr., Sievert A. Rohwer*, Howard A. Ross, John T. Rotenberry*, Stephen I. Rothstein, Ian C. R. Rowley*, Stephen M. Russell, John P. Ryder*, Edward I. Saiff, Paul Samollow*, W. Scherzinger, Dolph Schluter, Elizabeth Schreiber, Ralph W. Schreiber*, J. Michael Scott, Spencer G. Sealy*, William A. Searcy*, D. C. Seel, Sheldon R. Severinghaus, Thomas W. Sherry, William Shields*, Lester L. Short ${ }^{*}$ Gary W. Shugart*, H. H. Shugart, Charles G. Sibley, H. S. Siegel, Walter R. Siegfried, Rae Silver, Daniel Simberloff, Kimberly G. Smith*, Barbara Snow, David W. Snow*, Noel F. R. Snyder*, Paul R. Sotherland, William E. Southern*, Peter B. Stacey, John Staddon, Milton H. Stetson, F. Gary Stiles*, Chris Stinson*, Bernard Stonehouse, Robert W. Storer*, Joseph G. Strauch, Jr., Lawson G. Sugden, George Sugihara, Jeff Swinebroad, Stanley A. Temple*, Randy Thornhill, A. van Tienhoven, J. M. Tinbergen, Harrison B. Tordoff*, C. Richard Tracy, Joseph Travis, Fred W. Turek, Emil K. Urban, R. A. Väisänen, Beatrice Van Horne*, Sandra L. Vehrencamp, Jared Verner, A. Village, Carol Vleck, Robert B. Waide, Glenn Walsberg*, Hartmut Walter*, Jeff Walters, Adam Watson, Jeff Watson, Patrick J. Weatherhead*, Wesley W. Weathers*, Harmon P. Weeks, Jr., Charles M. Weise, Milton W. Weller, David F. Werschkul, Klaas Westerterp*, Clayton M. White*, Fred N. White, Bob Whitmore*, R. Haven Wiley*, David E. Willard, Edwin O. Willis*, Larry L. Wolf*, Glen E. Woolfenden*, S. Joseph Wright, Joseph M. Wunderle, Jr., Terry Yates*, Reto Zach*, Steve Zack*, Amotz Zahavi, Jerrold H. Zar*, and Richard L. Zusi*. 